\title{
The role of contextual factors on predicting entrepreneurial intention among Vietnamese students
}

\author{
Dương Công Doanh
}

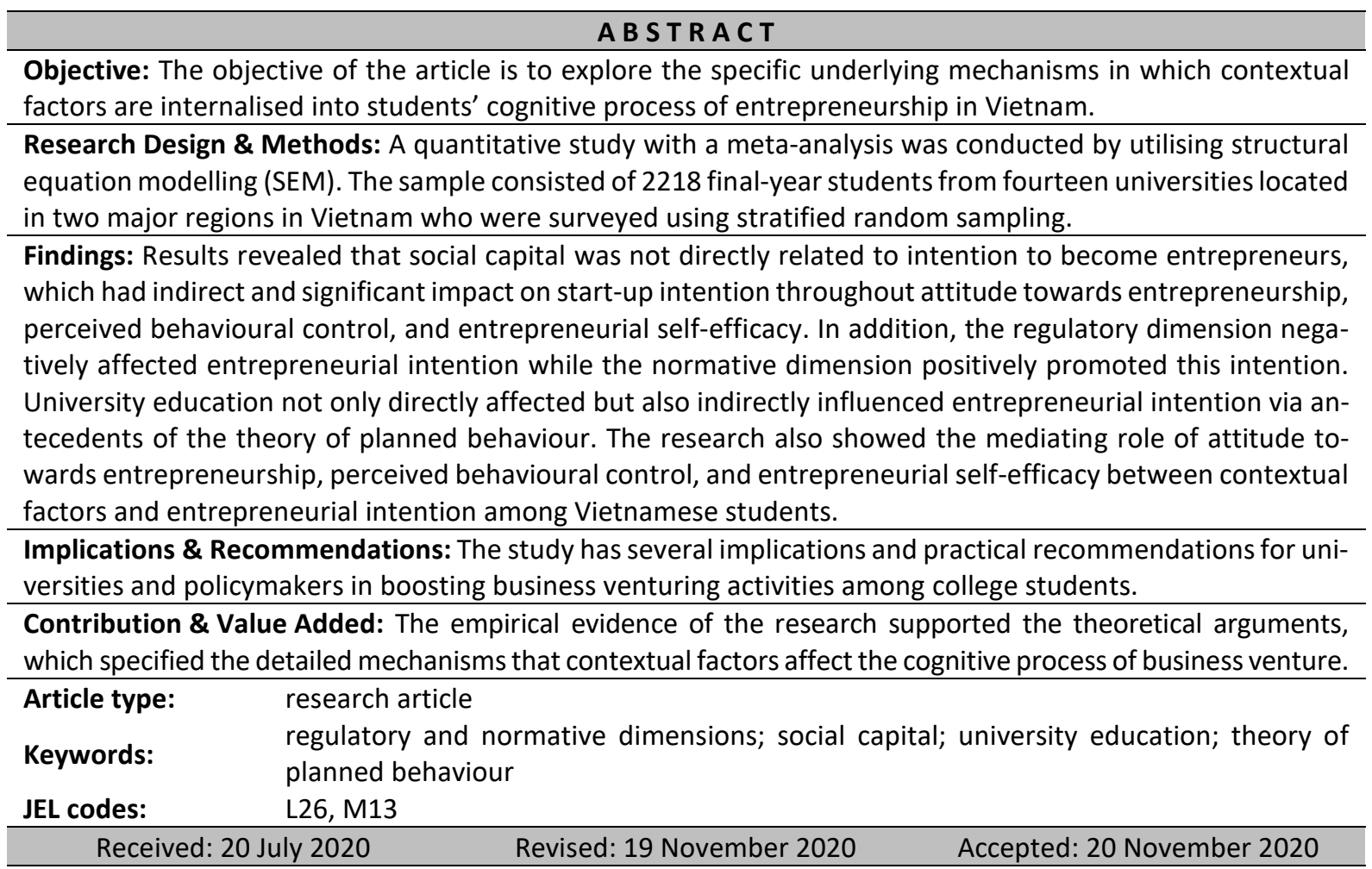

Suggested citation:

Doanh, D.C. (2021). The role of contextual factors on predicting entrepreneurial intention among Vietnamese students. Entrepreneurial Business and Economics Review, 9(1), 169-188. https://doi.org/10.15678/EBER.2021.090111

\section{INTRODUCTION}

Recently, we witness a drastic change in the labour market (Meoli, Fini, Sobrero, \& Wiklund, 2020). Working environment and traditional administrative structures transformed as a result of workforce diversity, increased internationalisation, and the rapid development of technologies, which results in a revolution in how people enact their career choices (Sullivan \& Baruch, 2009). For the youth - especially university students - business venture as a career gains in popularity (Edelman, Manolova, Shirokova, \& Tsukanova, 2016). Indeed, many policies fostering entrepreneurial activities - especially student entrepreneurship - have been proposed in both developed and developing countries, which translates into support policies and programmes by governments of many countries. Several policies showed positive effects, whereas other revealed only partial success (Baughn, Lim, Le, Neupert, \& Woods, 2006). The different outcomes of such efforts might reflect the inadequate awareness of some policymakers, involving the necessary drivers of entrepreneurship in diverse country contexts (Baughn 
et al., 2006). Thus, understanding why and how individuals seek or perform entrepreneurial behaviours might promote entrepreneurship activities more effectively and efficiently. Baugh et al. (2006) also emphasise that normative, social, and cognitive norms of business ventures derive from different contexts of countries in terms of historical, cultural, economics, and political perspectives.

The role of contextual variations in discovering entrepreneurial intention and behaviour is emphasised by many entrepreneurship scholars (e.g. Liñán \& Chen, 2009; Mueller \& Thomas, 2001; Hayton, George, \& Zahra, 2002; Vancea \& Utzet, 2017), while some agree that contextual factors are internalised by individuals to shape their cognitive process of business venture (Bercovitz \& Feldman, 2008; Turker \& Selcuk, 2009; Nguyen, Nguyen, \& Nguyen, 2018). However, the detailed mechanisms in which individuals' cognitive processes internalise contextual factors did not receive a clear answer. For instance, although individuals' motives to engage in entrepreneurship activities could be multifaceted (Nguyen, Bryant, Rose, Tseng, \& Kapasuwan, 2009), the question that still requires evident explanation is: how do contextual factors facilitate the process of a person's entrepreneurial cognitions? Indeed, Turker and Selcuk (2009) argue that most recent studies only focus on examining the role of some internal factors such as personal characteristics (Akanbi, 2013), individual motivations (Camelo-Ordaz, Dianez-Gonzalez, \& Ruiz-Navarro, 2016), and personal background (Bird \& Brush, 2002; Camelo-Ordaz, Dianez-Gonzalez, \& Ruiz-Navarro, 2016), rather than investigating the influence of external factors on shaping entrepreneurial intention. Moreover, Henderson and Robertson (2000) state that an individual's entrepreneurial perception is mostly driven by their innate characteristics. However, scholars reached a consensus that entrepreneurial traits and business aptitude should be nurtured by external environments (Henderson \& Robertson, 2000; Turker \& Selcuk, 2009). Thus, contextual factors can play a crucial role in configuring entrepreneurial intentions, even actual business venture behaviours (Kruja-Demneri, 2020). Thus, this study integrates insights from the theory of planned behaviour (Ajzen, 1991), contextual factors (e.g. country institutional profile; Busenitz, Gomez, \& Spencer, 2000), and the social learning theory (Bandura, 1977) to explore the specific mechanisms in which contextual factors are internalised into students' cognitive process of entrepreneurship in Vietnam. To the best of our understanding, no entrepreneurship literature examined the path from contextual factors to predict entrepreneurial self-efficacy and the cognitive process of entrepreneurship.

Particularly, this study considers the impact of two factors in the entrepreneurial ecosystem of educational environment (social capital and education university) and two other factors outside of the educational university environment (regulatory and normative dimensions) in shaping the cognitive process of business venture, which derives from attitude towards entrepreneurship, subjective norms, and perceived behavioural control to intention to become entrepreneurs among Vietnamese students. Besides discovering the effects of contextual factors - including the regulatory dimension - the normative dimension, capital, and university education on the cognitive process of entrepreneurship, this study also aims to discover the mediating roles of attitude towards entrepreneurship, subjective norms, and perceived behavioural control between contextual factors and entrepreneurial intention.

This study seeks to make three major contributions to entrepreneurship literature. Firstly, the study reveals that two antecedents of the educational environment in the entrepreneurial ecosystem - including educational university and social capital - play a significant role in the shaping of entrepreneurial self-efficacy, perceived behavioural control, and attitude towards entrepreneurship, then transformed into students' intention to become entrepreneurs. Secondly, the research shows that both dimensions of country profiles - regulatory and normative supports - are related to students' entrepreneurial intention. However, only normative norms promote entrepreneurial activities while the regulatory dimension impedes entrepreneurial intention among students. Finally, this study indicates that the theory of planned behaviour is effectively employed in transitional economies such as Vietnam.

The article conveys five main parts, which include introduction, literature review, materials and methods presentation, the elaboration of results and discussion, and a conclusion. 


\section{LITERATURE REVIEW}

\section{Theory of planned behaviour}

The theory of planned behaviour (TPB; Ajzen, 1991), which attempts to identify the cognitive determinants of behaviour, has been effectively implemented to estimate a variety of economic and special behaviours (Ajzen \& Fishbein, 2005). In entrepreneurship literature, Krueger and Carsrud (1993) posit that the cognitive process of business venture can be explained by the TPB because behavioural intention needs an enactive process of cognition that refers to personal beliefs, perceptions, and several another exogenous variables, which transform into an intention to conduct action and then transfer into actual action. Meanwhile, Bird and Jelinek (1988) define start-up intention as the degree of cognitive awareness in regard with the process of launching a new business venture. Indeed, cognitive psychology defines intention as a state of cognition immediately preceding a behaviour. Liñán, Santos, and Fernández (2011) also argue that - based on the TPB (Ajzen, 1991) - people's entrepreneurial decisions are inspired by three motivational factors, including attitudes towards a behaviour, subjective norms, and perceived behavioural control. Firstly, the attitude towards a behaviour reflects the level to which a person has a favourable or unfavourable assessment of a particular behaviour, which also depends on an individual's evaluation of the expected results/outcomes of the behaviour. Secondly, subjective norms refer to the perception of social pressures by an individual to perform or not to perform a specific behaviour, which reflects an individual's perception about whether close people encourage or discourage to perform a particular behaviour. Finally, perceived behavioural control refers to beliefs about the ease or difficulty of performing a specific task. It also shows the perceptions of the availability of resources, supports, and barriers to conduct a behaviour. The TPB might be applied to any behaviours that require a specific amount of planning. Thus, the TPB has been consistently confirmed as robust in exploring intentions and behaviours in different research fields. The decision to engage in business venture is determined as an intricate one, which is also examined as the outcome of complex cognitive processes. Thus, according to this meaning, the TPB is frequently employed to investigate this mental process that results in entrepreneurial acts (Liñán, 2008).

Numerous studies on business ventures show the relationships between three attitudinal components (attitude towards business venture, subjective norms, and perceived behavioural control) and the intention to become an entrepreneur (Gorgievski, Stephan, Laguna, \& Moriano, 2017). Nevertheless, existing literature on direct influences of subjective norms on start-up intention are rather inconsistent. While some studies argue that the link between subjective norms and entrepreneurial intention is significant (Othman \& Mansor, 2012; Solesvik, 2013; Maresch, Harms, Kailer, \& Wurm, 2015), other find this relationship lacking in empirical support (Miranda, Chamorro-Mera, \& Rubio, 2017). Lortie and Castogiovanni (2015) postulate that scholars should explore these links. Thus, I formulate the following hypotheses:

H1: Entrepreneurial intention is positively affected by (a) attitude towards entrepreneurship, (b) subjective norms, and (c) perceived behavioural control.

H2: Attitude towards entrepreneurship is positively affected by perceived behavioural control.

H3: Subjective norms are positively affected by (a) attitude towards entrepreneurship and (b) perceived behavioural control.

\section{Social learning theory}

Self-efficacy is identified as a central concept in the social learning theory proposed by Bandura (1977; 1982). The fundamental proposition of the social learning theory (or the self-efficacy theory) is that individuals' beliefs about their capacities and abilities to generate desired impacts by their own behaviours (Bandura, 1977). In entrepreneurship literature, there is a growing emphasis on the importance of entrepreneurial self-efficacy in recent studies, such as entrepreneurial career preferences, intentions, behaviour, entrepreneurial performance, and social entrepreneurship (e.g. Hand, Iskandarova, \& Blackburn, 2020; Marshall, Meek, Swab, \& Markin, 2020; Mozahem, \& Adlouni, 2020; To, Martínez, 
Orero-Blat, \& Chau, 2020; Yang, Li, \& Wang, 2020). Entrepreneurial self-efficacy is defined from various viewpoints (Tsai, Chang, \& Peng, 2014). Some define entrepreneurial self-efficacy as entrepreneurs' self-confidence in performing particular actions (Boyd \& Vozikis, 1994), while others describe it as an individual's confidence in his/her own capacities to conduct and achieve success in a business venture (Segal, Borgia, \& Schoenfeld, 2005). Some previous research shows that entrepreneurial self-efficacy has a strong impact on the intention to become entrepreneurs. For example, students with high entrepreneurial self-efficacy have a high intent to engage in business ventures (Liñán, Santos, \& Fernández, 2011) and even higher business venturing behaviour (Neto et al., 2018). Moreover, Boyd and Vozikis (1994) emphasise that entrepreneurial self-efficacy is an important factor that can explain the increase of intention to engage in business venture, but also the probability of transformation from intention to actual entrepreneurial behaviours.

Moreover, Bandura (1982) states that an individual's behaviour is significantly affected by his/her beliefs about the ability to perform actual action effectively, while control beliefs refer to attitude towards conducting a behaviour and perceived behavioural control (Ajzen, 1991). Thus, individuals with higher entrepreneurial self-efficacy can have an increased attitude towards entrepreneurship, perceived behavioural control, and intention to become entrepreneurs. Moreover, subjective norms demonstrate close peoples' approvals and supports (e.g. close friends, family, teachers), which refer to the performance of an actual behaviour (Ajzen, 1991; Liñán \& Chen, 2009), whereas self-efficacy can motivate entrepreneurial activities (Tsai, Chang, \& Peng, 2014). Thus, subjective norms may be connected with entrepreneurial self-efficacy. Gorgievski et al. (2017) and Tsai, Chang, and Peng (2014) postulate that scholars explore the correlation between entrepreneurial self-efficacy and three antecedents of the TPB. Thus, I formulate the following hypothesis:

H4: Entrepreneurial self-efficacy positively affects (a) attitude towards entrepreneurship, (b) subjective norms, (c) perceived behavioural control, and (d) entrepreneurial intention.

\section{Contextual factors}

The regulatory dimension is defined as legal, regulative, and governmental support for new business ventures, which also includes policies fascinating nascent entrepreneurs that decrease the risks of creating a new firm and acquiring the necessary resources for business activities (Busenitz, Gomez, \& Spencer, 2000). Rule-setting, controlling, monitoring, and even approving activities are included in regulatory processes (Scott, 1995). Enterprises can take advantage of resources available through sponsored and/or supportive programmes of governments. Moreover, entrepreneurs can capture opportunities steaming from policies proposed governments (Rondinelli \& Kasarda, 1992). Therefore, the government can encourage entrepreneurial activities through the policies which support nascent entrepreneurs and develop entrepreneurial ecosystem. In other words, viewed as the most formal of elements in the country institutional profile (Bruton \& Ahstrom, 2003), the regulatory dimension can significantly affect individuals' cognitive processes of entrepreneurship and their entrepreneurial self-efficacy. Nguyen (2020) state that these relationships should be further analysed. Therefore, I formulate the following hypothesis:

H5: The regulatory dimension positively affects (a) attitude towards entrepreneurship, (b) perceived behavioural control, (c) entrepreneurial self-efficacy and (d) entrepreneurial intention.

Normative support is defined as how much citizens admire business venturing activities, creativity, and innovation thinking. Moreover, it includes social norms, social beliefs, common values, and assumptions about human nature and behaviours that are socially assigned and performed (Busenitz, Gomez, \& Spencer, 2000), which consists of 'social norms, values, beliefs, and assumptions about human nature and human behaviour that are socially shared and carried by individuals' (Alvarez \& Urbano, 2012). Some prior studies confirm that the normative dimension affects business venture activities (Baughn et al., 2006; Oftedal, lakovleva, \& Foss, 2017; Turulja, Veselunovic, Agic, \& Pasic-Mesihovic, 2020). Spencer and Gomez (2004) suggest that the degree to which citizens respect business activities or admire entrepreneurs might predict entrepreneurship better than general dimensions of 
culture. Therefore, normative support may play a significant role in shaping students' cognitive processes of entrepreneurship and their entrepreneurial self-efficacy. Furthermore, Nguyen et al. (2020) postulate that we should consider the effects of normative supports on the cognitive process of entrepreneurship. As a result, I formulate the following hypothesis:

H6: The normative dimension positively affects (a) attitude towards entrepreneurship, (b) perceived behavioural control, (c) entrepreneurial self-efficacy, and (d) entrepreneurial intention.

Social capital is not only likely to strengthen the tangible and intangible assets of nascent entrepreneurs but also helps them to share information, establish collaborative networks, build trust in business transactions, and obtain essential resources (Adler \& Kwon, 2002). Nevertheless, the exact meaning of social capital was not clearly explained (Lang \& Fink, 2019; Poon, Thai, \& Naybor, 2012). Social capital reflects the supports from closest people - such as family and close friends - in order to help nascent entrepreneurs find the necessary resources to start own business (Davidsson \& Honig, 2003). Moreover, social capital shows the value of social networks (Adler \& Kwon, 2002). Therefore, social capital may be determined as the totality of supportive resources, consisting of both definite and potential supports that derive from long-term social relationships (Lang \& Fink, 2019; Yoon, Sun, \& Yulianti, 2015). Moreover, the links between social capital and intention to become entrepreneurs are explored by several previous studies (Ali \& Yousuf, 2019; Chia \& Liang, 2018; Mahfud, Triyono, Sudira, \& Mulyani, 2002; Liñán \& Santos, 2007). Social capital depicts such results as financial benefits and other entrepreneurial resources, meaning that people can be supported by social networks such as their family, friends, and relatives. Indeed, social capital is seen as a crucial factor in business opportunity recognition (Ali \& Yousuf, 2019) and encouraging entrepreneurial careers (Mahfud et al., 2020). To establish a new business, entrepreneurs are likely to access and acquire supportive resources from close relatives and social networks. The influence and support from close friends and family can be much more crucial than other cultural norms in shaping the cognitive process of entrepreneurship among nascent entrepreneurs and their entrepreneurial self-efficacy (Baughn et al., 2006; Bhagavatula, Elfring, van Tilburg, \& van de Bunt, 2010). Vuković, Kedmenec, Postolov, Jovanovski, and Korent (2017) postulate the investigation of correlations between social capital and the cognitive process of a business venture. Hence, I propose the following hypothesis:

H7: Social capital positively affects (a) attitude towards entrepreneurship, (b) perceived behavioural control, (c) entrepreneurial self-efficacy and (d) entrepreneurial intention.

Professional education in universities and institutions is seen as a great way to acquire essential knowledge about and necessary skills for entrepreneurship (Turker \& Selcuk, 2008). However, in a study focusing on students' personality traits, Wang and Wong (2004) emphasise that many students' start-up dreams may be impeded by inadequate preparation and insufficient business knowledge. Much more importantly, students may be are unwilling and inadequately prepared to take risks. Thus, academic education can play an important role in encouraging young people to consider business ventures as a career choice (Saeed, Yousafzai, Yani-de-soriano, \& Muffatto, 2013). However, some argue that university education is too academic and insufficient to encourage entrepreneurship (Morris \& Tsukanova, 2017). In order to promote entrepreneurial activities, many universities provide students with courses related to business and entrepreneurship to equip them with necessary knowledge and skills for business ventures (Turker \& Selcuk, 2008). Moreover, university education can build a dynamic ecosystem that significantly influences students' cognitive processes of business venturing (Fini, Grimaldi, Marzocchi, \& Sobrero, 2012). Uddin and Bose (2012) state that there is a strong link between university education and students' start-up intention. Meanwhile, Cox, Mueller, and Moss (2002) argue that university education can augment students' entrepreneurial self-efficacy via business courses and practical programmes. In Vietnam, a number of national programmes and actions were implemented by the government to promote business venture activities, for example 'Supporting students Entrepreneurship 2017-2020 with a vision towards 2025.' Hence, entrepreneurial education raised the interest of policymakers who seek to foster the country's enterprise development. Three elements are included in entrepreneurship education (Hoang, Le, Tran, \& Du, 2020), including curricular entrepre- 
neurship programmes, extracurricular entrepreneurship programmes, and social education in boosting entrepreneurial activities. Thus, entrepreneurship-related courses, such as new business venture creation, creativity, innovation, entrepreneurship, and new venture planning, were especially provided in programs at economic universities (Tung, Hung, Phuong, Loan, \& Chong, 2020). These courses equip students with essential knowledge and skills to run their own businesses. Lavelle (2019) argues that the relationship between university education and the three antecedents of TPB should be investigated. Thus, I formulate the following hypothesis:

H8: University education positively affects (a) attitude towards entrepreneurship, (b) perceived behavioural control, (c) entrepreneurial self-efficacy, and (d) entrepreneurial intention

Therefore, in the light of prior studies, I propose the following conceptual framework (Figure 1) so as to investigate the particular underlying mechanisms internalised in students' cognitive processes of business ventures in Vietnam, i.e. the contextual variables of social capital, university education, regulatory dimension, and normative dimension.

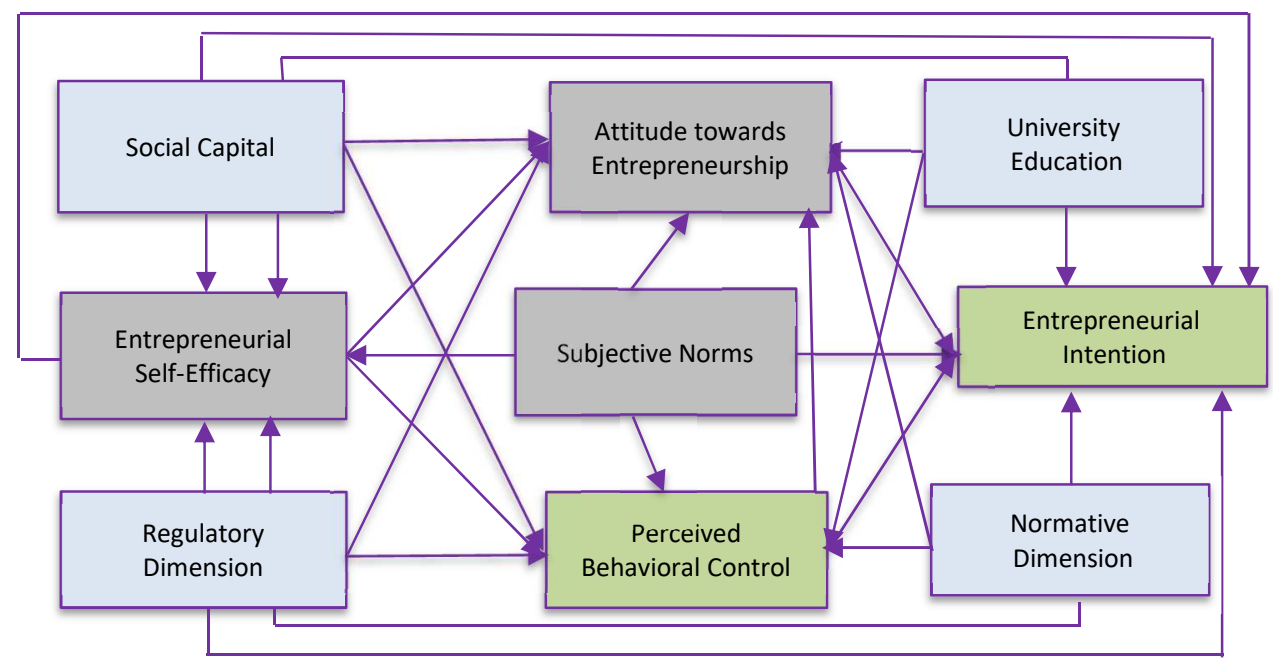

Figure 1. The conceptual model

Source: own elaboration.

\section{RESEARCH METHODOLOGY}

\section{Data collection and sample}

The sample consisted of 2218 undergraduate students recruited from 14 universities in Vietnam using stratified random sampling in a four-stage procedure. At the first stage, two main regions of Vietnam were selected, including the Northern and Southern areas with the demarcation line in Quang Tri province. Following the report of the Ministry of Education and Training (2018), 1707025 students were studying in 224 universities in Vietnam. Moreover, there were 123 universities located in the Northern and 101 in the Southern area. The second sampling stage randomly selected eight universities in the Northern region (National Economics University, Dai Nam University, Foreign Trade University, the University of Transport and Communications, Hanoi Open University, the National University of Civil Engineering, Thuongmai University, and the Hanoi University of Science and Technology) and six universities in the Southern region (Quy Nhon University, Hue University, the Da Nang University of Technology, Saigon University, the University of Economics Ho Chi Minh City, Dong Thap University), which followed university entrance scores per each region, that based on national university entrance exam. At the third stage, two to four classes each university were sampled in terms of fields of study. At the final sampling stage, research participants were recruited in the questionnaire directly distributed to college students aged 18 to 24 years. The participants were clearly informed about voluntary participation in the survey, that their responses would be confidential and secure, and the data would only be used for academic purposes. 
The majority of participants were studying and working part-time $(45.9 \%)$ or just studying (31.5\%). Only $5.7 \%$ participants were studying and running own businesses. There were $52.2 \%$ women and $54.6 \%$ students of economics. A large percentage of participants were in their final year (36.2\%), followed by second year (26.6\%), and third year (22.8\%). Most parents of participants had no relationship with business (56.1\%).

Table 1. Characteristics of participants

\begin{tabular}{|c|c|c|c|}
\hline Variables & Characteristics & Frequency & $\%$ \\
\hline \multirow[t]{2}{*}{ Gender } & Male & 1061 & 47.8 \\
\hline & Female & 1157 & 52.2 \\
\hline \multirow[t]{2}{*}{ Fields of study } & Economics & 1212 & 54.6 \\
\hline & Non-economics & 1006 & 45.4 \\
\hline \multirow[t]{4}{*}{ Years of study } & First year of college & 320 & 14.4 \\
\hline & Second year of college & 589 & 26.6 \\
\hline & Third year of college & 505 & 22.8 \\
\hline & Final year of college & 804 & 36.2 \\
\hline \multirow{4}{*}{$\begin{array}{l}\text { Types of current } \\
\text { professional activity }\end{array}$} & Only studying & 699 & 31.5 \\
\hline & studying and participating in a part-time work & 1018 & 45.9 \\
\hline & Studying and launching a business & 126 & 5.7 \\
\hline & Studying and searching for a secure job & 375 & 16.9 \\
\hline \multirow{4}{*}{$\begin{array}{l}\text { Mother's occupa- } \\
\text { tion }\end{array}$} & Self-employed & 608 & 27.4 \\
\hline & Staff in an organization & 294 & 13.3 \\
\hline & Manager in an organization & 71 & 3.2 \\
\hline & Others & 1245 & 56.1 \\
\hline \multirow[t]{4}{*}{ Father's occupation } & Self-employed & 575 & 25.9 \\
\hline & Staff in an organization & 261 & 11.8 \\
\hline & Manager in an organization & 137 & 6.2 \\
\hline & Others & 1245 & 56.1 \\
\hline
\end{tabular}

Source: own elaboration.

\section{Measures and Questionnaire Development}

All scales used in the study were adopted from prior studies, including social capital (Davidsson \& Honig, 2003; Baughn et al., 2006), university education (Turker \& Selcuk, 2008), regulatory and normative dimension (Busenitz, Gomez, \& Spencer, 2000), attitude towards entrepreneurship, perceived behaviour control and entrepreneurial intention (Liñán \& Chen, 2009), subjective norms (Liñán \& Chen, 2009), and entrepreneurial self-efficacy (Liñán, 2008; Tsai, Chang, \& Peng, 2014). I employed a fivepoint Likert-type format rated from 1 (strongly disagree) to 2 (strongly agree) in each construct. The final scales that extracted unsatisfactory items are represented in Table 2. Because the respondents are Vietnamese students, the observed variables (items) were first translated into Vietnamese from the original English version. Furthermore, some words have been modified to be better suit Vietnamese culture and context. Then, the questionnaire instrument was back translated into English to guarantee consistency between the original version and the translated one.

\section{Analyses}

A regression analysis was employed to evaluate the impact of contextual factors on students' cognitive processes in business ventures and the roles of mediators such as attitude towards business venture, subjective norms, and perceived behavioural control between environmental factors and students' intention to engage in a business venture. Firstly, the study examined the Cronbach's alpha and conducted explorative factor analysis (EFA) so as to scrutinise the internal consistency reliability of constructs in the conceptual framework. All constructs were likely to be satisfactory when the values of Cronbach's alpha exceeded 0.63 (Nunnally \& Bernstein, 1994). Simultaneously, the corrected itemtotal correlation of each observed variable (item) had to exceed 0.3 (Hair, Black, Babin, \& Anderson, 2010). Secondly, confirmatory factor analysis (CFA) was utilised to estimate the reliability and validity 
of the variables (scales), which was adopted since this approach could have been employed to examine whether measures of constructs with the nature of that scales are appropriate or not (Nunnally \& Bernstein, 1994), which has been broadly utilised in studies of the social field (Hair et al. 2010; Tsai, Chang, \& Peng 2014). Finally, structural equation modelling (SEM) was used to estimate path coefficients for each hypothesised link in the research model. Goodness of fit of the measurement model was considered using $\chi^{2}$ (Chi-square Statistics), $\chi^{2} / D F$ (Chi-Square/Degree of Freedom), CFI (Comparative Fit Index), TLI (Tucker-Lewis Index), GFI (Goodness-of-Fit). However, $\chi^{2}$ and $\chi^{2} / D F$ were impressionable to sample size (Jöreskog \& Sörbom 1993), thus, the CFI, TLI, and RMSEA were utilised. A CFI of over 0.90 is ideal (Bentler \& Bonett, 1980), while one exceeding 0.95 is an excellent fit (Hu \& Bentler, 1999). RMSEA value lower than 0.05 demonstrates a good fit, while between 0.05 and 0.08 indicates a reasonable fit (Browne \& Cudeck, 1993). Moreover, the indirect effects or the mediating roles were examined utilising a bootstrapping approach with 6000 replications and the confidence degree of $90 \%$ (Shrout \& Bolger, 2002; Preacher \& Hayes, 2008).

\section{RESULTS AND DISCUSSION}

\section{Measure assessment}

The Cronbach's alpha of all constructs was tested. Initial results indicated that ATE1 was extracted due to the corrected item-total correlation being lower than 0.3, while EI1 and EI2 were removed because their values of Cronbach's alpha were higher than that of the 'entrepreneurial intention' construct. After extracting unmoderated items, the Cronbach's alpha of all scales varied from 0.761 (Normative dimension-ND) to 0.918 (Entrepreneurial intention-EI). Moreover, all corrected item-total correlation of each item in scales were higher than 0.3.

Initially, the total of 36 items of all variables were used in the exploratory factor analysis (EFA) with principal axis factoring (Promax), while the initial results of testing the reliability of scales by $\mathrm{EFA}$ revealed that $\mathrm{KMO}=0.907$; Sig. of Bartlett's Test of Sphericity $=0.000<0.05$; Cumulative (\%)= $65.740>50 \%$; and Eigenvalues $=1.053>1$. However, factor loadings of PBC5, PBC6, SC1, and ESE1 were lower than 0.5 . Thus, these items were extracted from constructs before conducting confirmatory factor analysis (CFA). The final results of EFA represented that $K M O=0.888$, Sig. of Bartlett's Test of Sphericity $=0.000<0.05$; Cumulative $(\%)=68.228>50 \%$; and Eigenvalues $=1.019>1$. Thus, the validity of all scales were confirmed after extracting unsatisfactory items. The final results of Cronbach's alpha and pattern matrix is presented in Table 2.

Table 2. Cronbach's Alpha and Pattern Matrix after extracting unmoderated items

\begin{tabular}{|c|c|c|c|c|c|c|c|c|c|c|}
\hline \multirow{2}{*}{ Items } & \multicolumn{9}{|c|}{ Factor } & \multirow{2}{*}{$\begin{array}{l}\text { Cronb } \\
\text { ach's } \\
\text { alpha }\end{array}$} \\
\hline & F1 & F2 & F3 & F4 & F5 & F6 & F7 & F8 & F9 & \\
\hline \multicolumn{10}{|l|}{ Regulatory Dimension (RD) } & 0.874 \\
\hline $\begin{array}{l}\text { RD4. The government sponsors organizations that } \\
\text { help new business develop }\end{array}$ & 0.810 & & & & & & & & & 0.836 \\
\hline $\begin{array}{l}\text { RD2. The government set aside government con- } \\
\text { tracts for new and small businesses }\end{array}$ & 0.794 & & & & & & & & & 0.840 \\
\hline $\begin{array}{l}\text { RD3. Local and national governments have special } \\
\text { support available for individual who want to start a } \\
\text { new business }\end{array}$ & 0.769 & & & & & & & & & 0.848 \\
\hline $\begin{array}{l}\text { RD1. Government organization in this country assist } \\
\text { individuals with starting their own business }\end{array}$ & 0.733 & & & & & & & & & 0.853 \\
\hline $\begin{array}{l}\text { RD5. Even after failing in an earlier business, the } \\
\text { government assists entrepreneurs in starting again }\end{array}$ & 0.711 & & & & & & & & & 0.858 \\
\hline \multicolumn{10}{|l|}{ Social Capital (SC) } & 0.811 \\
\hline $\begin{array}{l}\text { SC5. If I started a business, my friends would help } \\
\text { me to succeed }\end{array}$ & & 0.777 & & & & & & & & 0.761 \\
\hline
\end{tabular}




\begin{tabular}{|c|c|c|c|c|c|c|c|c|c|c|}
\hline \multirow[b]{2}{*}{ Items } & \multicolumn{9}{|c|}{ Factor } & \multirow{2}{*}{$\begin{array}{l}\text { Cronb } \\
\text { ach's } \\
\text { alpha }\end{array}$} \\
\hline & $\mathbf{F 1}$ & F2 & F3 & F4 & F5 & F6 & F7 & F8 & F9 & \\
\hline $\begin{array}{l}\text { SC4. My friend would want me to start my own } \\
\text { business }\end{array}$ & & 0.676 & & & & & & & & 0.774 \\
\hline $\begin{array}{l}\text { SC2. If I started a new business, my family members } \\
\text { with help me to succeed }\end{array}$ & & 0.637 & & & & & & & & 0.774 \\
\hline $\begin{array}{l}\text { SC3. If I started a new business, some members my } \\
\text { family would work with me }\end{array}$ & & 0.685 & & & & & & & & 0.779 \\
\hline $\begin{array}{l}\text { SC6. If I started a business, some of my friends } \\
\text { would work with me }\end{array}$ & & 0.586 & & & & & & & & 0.785 \\
\hline \multicolumn{10}{|l|}{ Perceived Behavioural Control (PBC) } & 0.820 \\
\hline $\begin{array}{l}\text { PBC3. I can control the creation process of a new } \\
\text { firm }\end{array}$ & & & 0.790 & & & & & & & 0.734 \\
\hline PBC2. I am prepared to start a viable firm & & & 0.846 & & & & & & & 0.745 \\
\hline $\begin{array}{l}\text { PBC4. I know the necessary practical details to start } \\
\text { a firm }\end{array}$ & & & 0.600 & & & & & & & 0.799 \\
\hline $\begin{array}{l}\text { PBC1. To start a firm and keep it working would be } \\
\text { easy for me }\end{array}$ & & & 0.631 & & & & & & & 0.809 \\
\hline \multicolumn{10}{|l|}{ Attitude Towards Entrepreneurship (ATE) } & 0.826 \\
\hline $\begin{array}{l}\text { ATE4. Being an entrepreneur would entail great } \\
\text { satisfactions for me }\end{array}$ & & & & 0.835 & & & & & & 0.759 \\
\hline $\begin{array}{l}\text { ATE5. Among various options, I would rather be an } \\
\text { entrepreneur }\end{array}$ & & & & 0.761 & & & & & & 0.765 \\
\hline $\begin{array}{l}\text { ATE2. A career as an entrepreneur is attractive for } \\
\text { me }\end{array}$ & & & & 0.733 & & & & & & 0.780 \\
\hline $\begin{array}{l}\text { ATE3. If I had an opportunity and resources, I'd like } \\
\text { to start a firm }\end{array}$ & & & & 0.661 & & & & & & 0.816 \\
\hline \multicolumn{10}{|l|}{ Entrepreneurial Self-efficacy (ESE) } & 0.840 \\
\hline $\begin{array}{l}\text { ESE4. I can see new market opportunities for new } \\
\text { products and services }\end{array}$ & & & & & 0.843 & & & & & 0.780 \\
\hline $\begin{array}{l}\text { ESE3. I can develop and maintain favourable rela- } \\
\text { tionships with potential investors }\end{array}$ & & & & & 0.838 & & & & & 0.786 \\
\hline $\begin{array}{l}\text { ESE5. I can develop a working environment that en- } \\
\text { courages people to try out something new }\end{array}$ & & & & & 0.669 & & & & & 0.801 \\
\hline $\begin{array}{l}\text { ESE2. I show great aptitude for leadership and } \\
\text { problem-solving }\end{array}$ & & & & & 0.549 & & & & & 0.819 \\
\hline \multicolumn{10}{|l|}{ University Education (UE) } & 0.846 \\
\hline $\begin{array}{l}\text { UE1. The education in university encourages me to } \\
\text { develop creative ideas for being an entrepreneur }\end{array}$ & & & & & & 0.862 & & & & 0.753 \\
\hline $\begin{array}{l}\text { UE2. My university provides the necessary } \\
\text { knowledge about entrepreneurship }\end{array}$ & & & & & & 0.798 & & & & 0.794 \\
\hline $\begin{array}{l}\text { UE3. My university develops my entrepreneurial } \\
\text { skills and abilities }\end{array}$ & & & & & & 0.754 & & & & 0.807 \\
\hline \multicolumn{10}{|l|}{ Normative Dimension (ND) } & 0.761 \\
\hline $\begin{array}{l}\text { ND2. In this country, innovative and creative think- } \\
\text { ing is viewed as the routes to success }\end{array}$ & & & & & & & 0.846 & & & 0.647 \\
\hline ND3. Entrepreneurs are admired in this country & & & & & & & 0.709 & & & 0.702 \\
\hline $\begin{array}{l}\text { ND4. People in this country tend to greatly admire } \\
\text { those who start their own business }\end{array}$ & & & & & & & 0.575 & & & 0.728 \\
\hline $\begin{array}{l}\text { ND1. Turning new ideas into businesses is an ad- } \\
\text { mired career path in this country }\end{array}$ & & & & & & & 0.541 & & & 0.736 \\
\hline \multicolumn{10}{|l|}{ Subjective Norms (SN) } & 0.851 \\
\hline $\begin{array}{l}\text { SN2. If I decided to create a firm, my closest friends } \\
\text { would approve of that decision }\end{array}$ & & & & & & & & 0.837 & & 0.758 \\
\hline
\end{tabular}




\begin{tabular}{|c|c|c|c|c|c|c|c|c|c|c|}
\hline \multirow{2}{*}{ Items } & \multicolumn{9}{|c|}{ Factor } & \multirow{2}{*}{\begin{tabular}{|l} 
Cronb \\
ach's \\
alpha
\end{tabular}} \\
\hline & F1 & F2 & F3 & F4 & F5 & F6 & F7 & F8 & F9 & \\
\hline $\begin{array}{l}\text { SN3. If I decided to create a firm, people who are } \\
\text { important to me would approve of that decision }\end{array}$ & & & & & & & & 0.772 & & 0.792 \\
\hline $\begin{array}{l}\text { SN1. If I decided to create a firm, my closest family } \\
\text { would approve of that decision }\end{array}$ & & & & & & & & 0.795 & & 0.827 \\
\hline \multicolumn{10}{|l|}{ Entrepreneurial Intention (EI) } & 0.918 \\
\hline El5. I have very seriously thoughts of starting a firm & & & & & & & & & 0.952 & 0.874 \\
\hline E16. I have a firm intention to start a firm someday & & & & & & & & & 0.822 & 0.892 \\
\hline El4. I am determined to create a firm in the future & & & & & & & & & 0.898 & 0.895 \\
\hline $\begin{array}{l}\text { El3. I will make every effort to start and run my } \\
\text { own firm. }\end{array}$ & & & & & & & & & 0.765 & 0.911 \\
\hline \multicolumn{7}{|l|}{ Kaiser-Meyer-Olkin (KMO) Measure of Sampling Adequancy } & \multicolumn{4}{|l|}{0.907} \\
\hline \multicolumn{7}{|l|}{ Sig. (Bartlett's Test of Spericity) } & \multicolumn{4}{|l|}{0.000} \\
\hline \multicolumn{7}{|l|}{ Cumulative (\%) } & \multicolumn{4}{|c|}{$68.228 \%$} \\
\hline The Value of Initial Eigenvalue & & & & & & & 1.019 & & & \\
\hline
\end{tabular}

Source: own study.

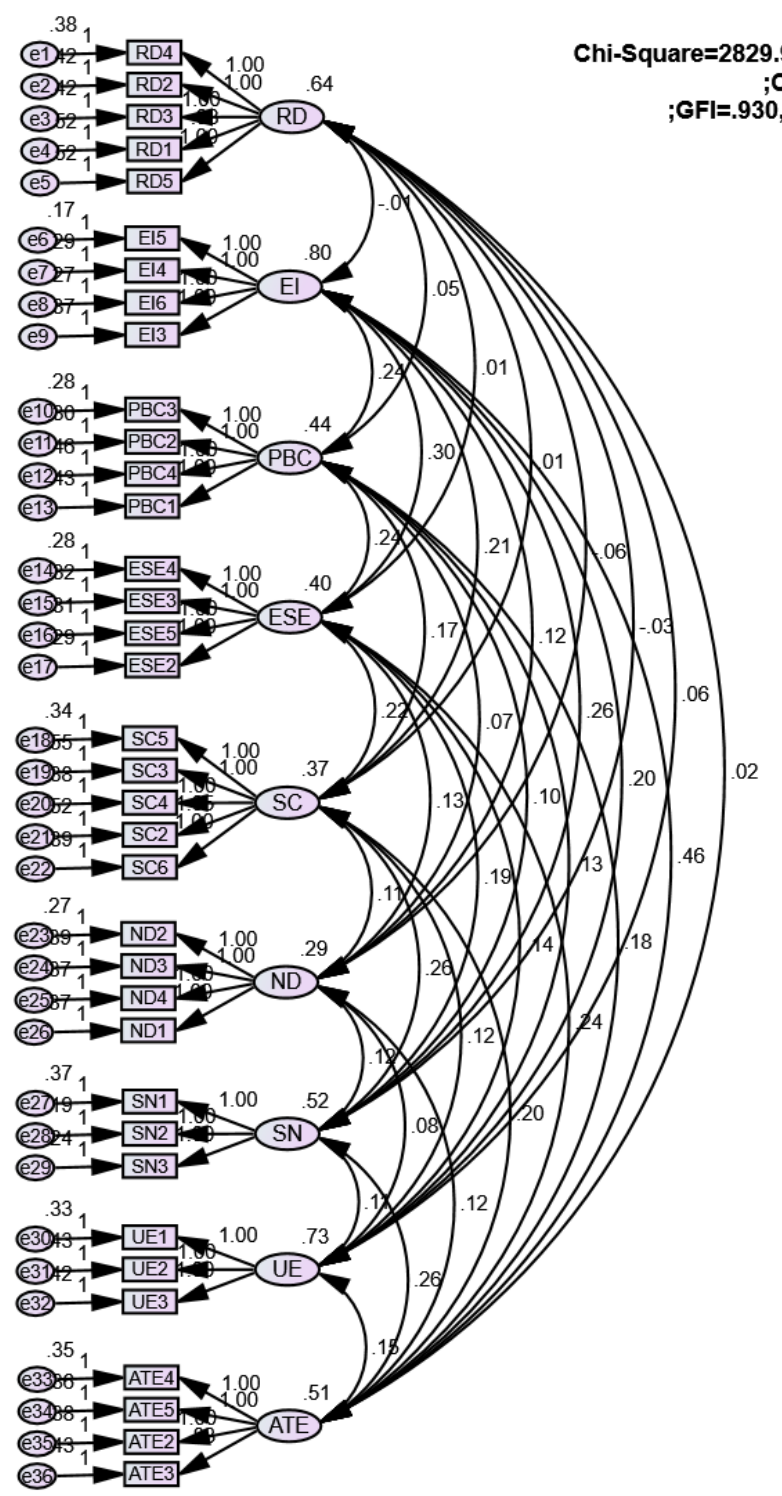

Figure 2. The results of confirmatory factor analysis Source: own elaboration. 
Then, the reliability, convergent validity, and discriminant validity of each construct was examined by utilising confirmatory factor analysis (CFA). A number of highly recommended indices were considered to examine the model's fitness. The fit indices represented the model fit data reasonably well (CMIN/DF $=4.862<5 ; \mathrm{GFI}=0.930 ; \mathrm{CFI}=0.942 ; \mathrm{TLI}=0.938>0.9 ;$ and RMSEA $=0.042<0.5 ;$ Browne \& Cudeck, 1993; Hu \& Bentler, 1999).

I tested the average variance extracted (AVE), composite reliability (CR), and maximum shared variance (MSV) to show the reliability, convergent validity, and discriminant validity of the constructs (Anderson \& Gerbing, 1988; Hair et al., 2010). As indicated in Table 3, CR values for all variables were demonstrated to be higher than 0.70 , the lowest $C R$ value was witnessed in the normative dimension (0.769). Furthermore, all the AVE values were within their recommended level with a value higher than 0.45. Moreover, the MSV values of all constructs were lower than their AVE (Hair et al., 2010). The results of confirmatory factor analysis (CFA) also indicated that all items had a standardised regression weight higher than 0.5 , with only SC3 having the lowest value at 0.634 .

Table 3. The reliability, convergent and discriminant validity of variables

\begin{tabular}{|l|c|c|c|c|c|c|c|c|c|c|c|c|c|}
\hline $\begin{array}{c}\text { Varia- } \\
\text { bles }\end{array}$ & CR & AVE & MSV & MaxR(H) & ATE & RD & EI & SC & ND & SN & UE & PBC & ESE \\
\hline ATE & 0.829 & 0.549 & 0.523 & 0.833 & $\mathbf{0 . 7 4 1}$ & & & & & & & & \\
\hline RD & 0.876 & 0.585 & 0.020 & 0.877 & 0.027 & $\mathbf{0 . 7 6 5}$ & & & & & & & \\
\hline EI & 0.922 & 0.746 & 0.523 & 0.926 & 0.723 & -0.009 & $\mathbf{0 . 8 6 4}$ & & & & & & \\
\hline SC & 0.813 & 0.466 & 0.346 & 0.816 & 0.460 & 0.014 & 0.396 & $\mathbf{0 . 6 8 3}$ & & & & & \\
\hline ND & 0.769 & 0.454 & 0.150 & 0.770 & 0.320 & -0.140 & 0.255 & 0.351 & $\mathbf{0 . 6 7 4}$ & & & & \\
\hline SN & 0.855 & 0.663 & 0.346 & 0.861 & 0.511 & -0.046 & 0.398 & 0.588 & 0.314 & $\mathbf{0 . 8 1 4}$ & & & \\
\hline UE & 0.848 & 0.650 & 0.070 & 0.849 & 0.245 & 0.092 & 0.257 & 0.234 & 0.183 & 0.179 & $\mathbf{0 . 8 0 6}$ & & \\
\hline PBC & 0.830 & 0.551 & 0.329 & 0.834 & 0.382 & 0.099 & 0.410 & 0.421 & 0.201 & 0.218 & 0.233 & $\mathbf{0 . 7 4 2}$ & \\
\hline ESE & 0.839 & 0.566 & 0.332 & 0.840 & 0.540 & 0.018 & 0.534 & 0.576 & 0.387 & 0.427 & 0.264 & 0.574 & $\mathbf{0 . 7 5 3}$ \\
\hline
\end{tabular}

Note: ATE: Attitude towards entrepreneurship; SN: Subjective norms; PBC: Perceived behavioural control; El: Entrepreneurial intention; RD: Regulatory dimension; ND: Normative dimension; ESE: Entrepreneurial self-efficacy; SC: Social capital; UE: University education.

Source: own study.

\section{Structural model}

The structural model was conducted to validate the conceptual framework and estimate the relationships in the research model. Similar to the confirmatory factor analysis (CFA) - determined as the measurement model - the structural model fully corresponded with the observed dataset as its fitted indication appeared within the accepted degrees: CMIN/DF $=5.474 ; \mathrm{GFI}=0.926 ; \mathrm{CFI}=0.935 ; \mathrm{TLI}$ $=0.928$; and RMSEA $=0.046$ (Browne \& Cudeck, 1993; Hu \& Bentler, 1999). A satisfactory predictive validity was achieved by the conceptual framework as well.

Research results revealed that the total of 26 correlations were tested. Twenty out of 26 hypotheses were statistically significant, six of them were not significantly supported by the research dataset.

In terms of direct relationship, the results showed that attitude towards entrepreneurship had the strongest effect on students' intention to engage in business venturing $(\gamma=0.791 ; p<0.001)$, followed by start-up self-efficacy $(\gamma=0.268 ; p<0.001)$, and perceived behavioural control $(\gamma=0.145$; $p<0.001)$. University education was positively linked to the intention to become an entrepreneur, but the effect level was rather weak $(\gamma=0.062 ; p=0.002<0,01)$. However, the regulatory dimension negatively affected entrepreneurial intention $(\gamma=-0.058 ; p=0.008<0,01)$. Besides, there appeared no statistical significance to indicate that subjective norms, social capital, and normative dimension correlates with entrepreneurial intention $(p>0.05)$. These results are similar to previous studies that tested the relationship between attitude towards entrepreneurship (Liñán, Nabi, \& Krueger, 2013; Dinc \& Budic, 2016), subjective norms (Liñán, 2008; Maes Leroy, \& Sels, 2014), perceived behavioural control (Liñán \& Chen, 2009; Traikova, Manolova, Mollers, \& Buchenrieder, 2017), entrepreneurial self-efficacy (Tsai, Chang, \& Peng, 2014), and entrepreneurial intention. 
Entrepreneurial self-efficacy significantly correlated with both attitude towards entrepreneur$\operatorname{ship}(\gamma=0.345 ; p<0.001)$ and perceived behavioural control $(\gamma=0.540 ; p<0.001)$. Thus, high entrepreneurial self-efficacy can augment individuals' attitude towards entrepreneurship and perceived behavioural control and then enhance their entrepreneurial intention $\left(\gamma_{\text {indirect ESE-EI }}=0.404\right)$. This study confirmed that start-up self-efficacy and perceived behavioural control were two different variables because the influencing degrees of these constructs on other factors were totally different (Tsai, Chang, \& Peng, 2014).

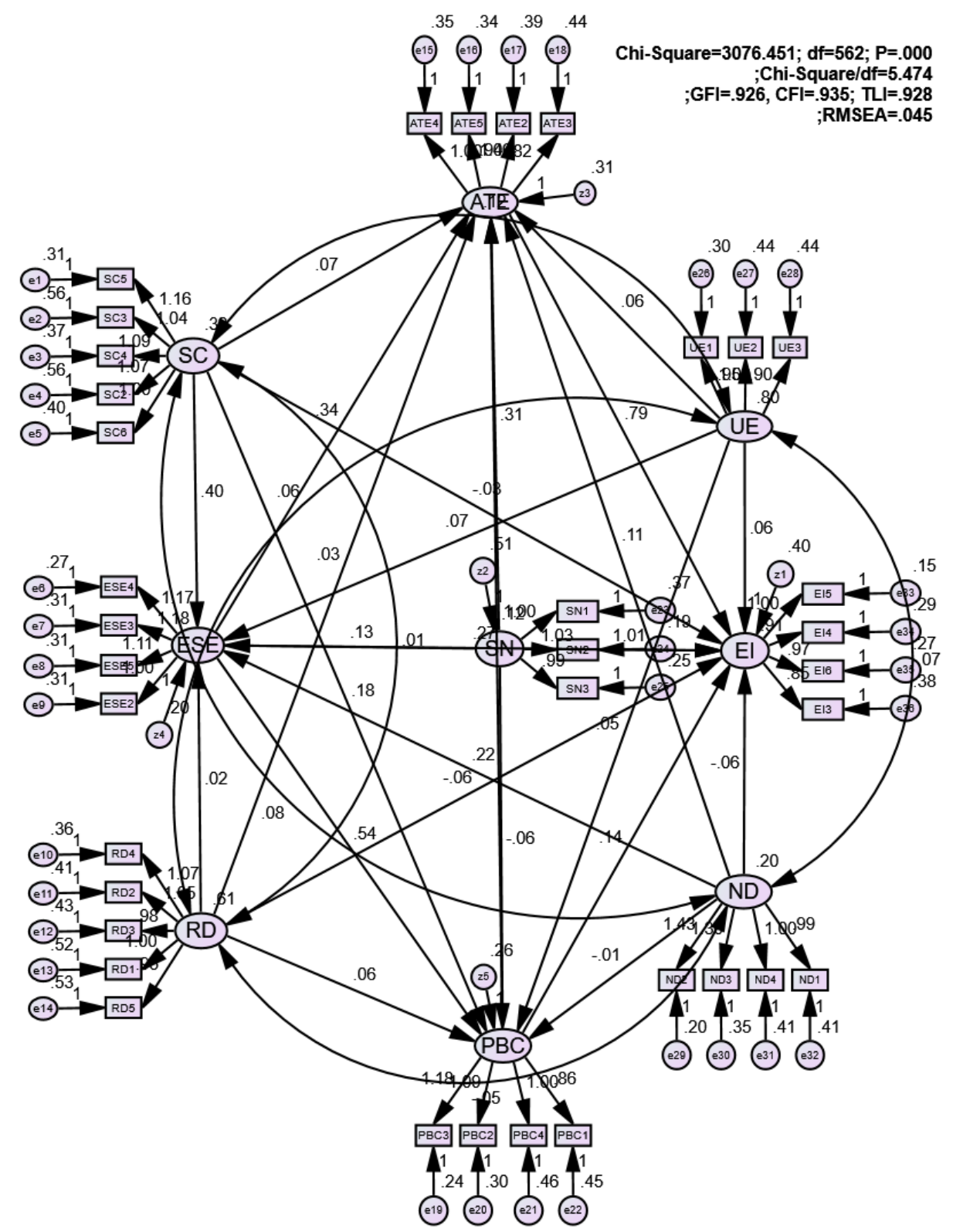

Figure 3. Structural model (standardised estimates) Source: own elaboration.

From close entrepreneurial supports aspects, even though social capital was not directly related to entrepreneurial intention, it had indirect effects on attitude towards entrepreneurship and entrepreneurial intention throughout entrepreneurial self-efficacy and perceived behavioural control $\left(\gamma_{\text {indirect SC-ATE }}=0.188 ; \gamma_{\text {indirect SC-El }}=0.373\right)$. Thus, support from close friends and family can boost startup self-efficacy, attitude towards entrepreneurship, perceived behavioural control, and then increase intentions to become entrepreneurs among students. These results reflect the important role 
of social capital in shaping entrepreneurial self-efficacy and the cognitive process of business venture (Baughn et al., 2006; Vuković et al., 2017).

Table 4. The results of structural path analysis

\begin{tabular}{|c|c|c|c|c|c|c|c|c|}
\hline \multicolumn{4}{|c|}{ Hypotheses } & Estimates & S.E & C.R & P-value & Description \\
\hline $\mathrm{H} 1 \mathrm{a}$ & ATE & $\rightarrow$ & $\mathrm{EI}$ & 0.791 & 0.037 & 21.300 & $* * *$ & Supported \\
\hline $\mathrm{H} 1 \mathrm{~b}$ & SN & $\rightarrow$ & $\mathrm{EI}$ & 0.007 & 0.027 & 0.257 & 0.798 & Not supported \\
\hline $\mathrm{H} 1 \mathrm{c}$ & PBC & $\rightarrow$ & $\mathrm{EI}$ & 0.145 & 0.036 & 4.037 & $* * *$ & Supported \\
\hline $\mathrm{H} 2$ & PBC & $\rightarrow$ & ATE & 0.123 & 0.032 & 3.864 & $* * *$ & Supported \\
\hline $\mathrm{H} 3 \mathrm{a}$ & SN & $\rightarrow$ & ATE & 0.313 & 0.023 & 13.525 & $* * *$ & Supported \\
\hline $\mathrm{H} 3 \mathrm{~b}$ & SN & $\rightarrow$ & PBC & -0.062 & 0.020 & -3.157 & 0.002 & Supported \\
\hline $\mathrm{H} 4 \mathrm{a}$ & ESE & $\rightarrow$ & ATE & 0.345 & 0.043 & 8.051 & $* * *$ & Supported \\
\hline $\mathrm{H} 4 \mathrm{~b}$ & SN & $\rightarrow$ & ESE & 0.128 & 0.017 & 7.490 & $* * *$ & Supported \\
\hline $\mathrm{H} 4 \mathrm{c}$ & ESE & $\rightarrow$ & PBC & 0.540 & 0.038 & 14.278 & $* * *$ & Supported \\
\hline $\mathrm{H} 4 \mathrm{~d}$ & ESE & $\rightarrow$ & $\mathrm{EI}$ & 0.268 & 0.049 & 5.470 & $* * *$ & Supported \\
\hline $\mathrm{H} 5 \mathrm{a}$ & $\mathrm{RD}$ & $\rightarrow$ & ATE & 0.025 & 0.019 & 1.300 & 0.194 & Not supported \\
\hline $\mathrm{H} 5 \mathrm{~b}$ & $\mathrm{RD}$ & $\rightarrow$ & PBC & 0.062 & 0.018 & 3.487 & $* * *$ & Supported \\
\hline $\mathrm{H} 5 \mathrm{c}$ & $\mathrm{RD}$ & $\rightarrow$ & ESE & 0.024 & 0.016 & 1.540 & 0.124 & Not supported \\
\hline $\mathrm{H} 5 \mathrm{~d}$ & $\mathrm{RD}$ & $\rightarrow$ & $\mathrm{EI}$ & -0.058 & 0.022 & -2.653 & 0.008 & Supported \\
\hline $\mathrm{H6a}$ & ND & $\rightarrow$ & ATE & 0.108 & 0.039 & 2.769 & 0.006 & Supported \\
\hline $\mathrm{H} 6 \mathrm{~b}$ & ND & $\rightarrow$ & PBC & -0.009 & 0.036 & -0.241 & 0.810 & Not supported \\
\hline $\mathrm{H} 6 \mathrm{c}$ & ND & $\rightarrow$ & ESE & 0.225 & 0.032 & 7.083 & $* * *$ & Supported \\
\hline $\mathrm{H} 6 \mathrm{~d}$ & ND & $\rightarrow$ & $\mathrm{EI}$ & -0.061 & 0.044 & -1.397 & 0.162 & Not supported \\
\hline $\mathrm{H7a}$ & SC & $\rightarrow$ & ATE & 0.073 & 0.035 & 2.107 & 0.035 & Supported \\
\hline $\mathrm{H} 7 \mathrm{~b}$ & SC & $\rightarrow$ & PBC & 0.184 & 0.032 & 5.777 & $* * *$ & Supported \\
\hline $\mathrm{H} 7 \mathrm{c}$ & $\mathrm{SC}$ & $\rightarrow$ & ESE & 0.403 & 0.027 & 14.676 & $* * *$ & Supported \\
\hline $\mathrm{H} 7 \mathrm{~d}$ & SC & $\rightarrow$ & $\mathrm{El}$ & -0.032 & 0.039 & -0.834 & 0.405 & Not supported \\
\hline $\mathrm{H} 8 \mathrm{a}$ & UE & $\rightarrow$ & ATE & 0.058 & 0.018 & 3.229 & 0.001 & Supported \\
\hline $\mathrm{H} 8 \mathrm{~b}$ & UE & $\rightarrow$ & PBC & 0.047 & 0.016 & 2.865 & 0.004 & Supported \\
\hline $\mathrm{H} 8 \mathrm{c}$ & UE & $\rightarrow$ & ESE & 0.068 & 0.014 & 4.799 & $* * *$ & Supported \\
\hline $\mathrm{H} 8 \mathrm{~d}$ & UE & $\rightarrow$ & $\mathrm{El}$ & 0.062 & 0.020 & 3.077 & 0.002 & Supported \\
\hline
\end{tabular}

Note: ${ }^{* * *}<0.001$; ATE: Attitude towards entrepreneurship; SN: Subjective norms; PBC: Perceived behavioural control; El: Entrepreneurial intention; RD: Regulatory dimension; ND: Normative dimension; ESE: Entrepreneurial self-efficacy; SC: Social capital; UE: University education.

Source: own study.

Table 5. Total effects of variables using bootstrapping (6000 replications)

\begin{tabular}{|c|c|c|c|c|c|c|c|c|c|}
\hline \multirow{2}{*}{$\begin{array}{c}\text { Dependent } \\
\text { variables }\end{array}$} & \multirow{2}{*}{ Effects } & \multicolumn{8}{|c|}{ Independent variables } \\
\hline & & ND & UE & RD & SC & ESE & SN & PBC & ATE \\
\hline \multirow{3}{*}{ ESE } & Direct & 0.225 & 0.068 & 0.000 & 0.403 & 0.000 & 0.128 & 0.000 & 0.000 \\
\hline & Indirect & 0.000 & 0.000 & 0.000 & 0.000 & 0.000 & 0.000 & 0.000 & 0.000 \\
\hline & Total & 0.225 & 0.068 & 0.000 & 0.403 & 0.000 & 0.128 & 0.000 & 0.000 \\
\hline \multirow{3}{*}{ PBC } & Direct & 0.000 & 0.016 & 0.062 & 0.184 & 0.540 & -0.062 & 0.000 & 0.000 \\
\hline & Indirect & 0.121 & 0.037 & 0.000 & 0.217 & 0.000 & 0.069 & 0.000 & 0.000 \\
\hline & Total & 0.121 & 0.053 & 0.062 & 0.401 & 0.540 & 0.007 & 0.000 & 0.000 \\
\hline \multirow{3}{*}{ ATE } & Direct & 0.108 & 0.058 & 0.025 & 0.073 & 0.345 & 0.313 & 0.123 & 0.000 \\
\hline & Indirect & 0.091 & 0.034 & 0.017 & 0.188 & 0.066 & 0.045 & 0.000 & 0.000 \\
\hline & Total & 0.199 & 0.092 & 0.042 & 0.261 & 0.411 & 0.358 & 0.123 & 0.000 \\
\hline \multirow{3}{*}{ EI } & Direct & 0.000 & 0.062 & -0.058 & 0.000 & 0.268 & 0.000 & 0.145 & 0.791 \\
\hline & Indirect & 0.235 & 0.103 & 0.051 & 0.373 & 0.404 & 0.318 & 0.097 & 0.000 \\
\hline & Total & 0.235 & 0.165 & -0.007 & 0.373 & 0.672 & 0.318 & 0.145 & 0.791 \\
\hline
\end{tabular}

Note: ATE: Attitude towards entrepreneurship; SN: Subjective norms; PBC: Perceived behavioural control; El: Entrepreneurial intention; RD: Regulatory dimension; ND: Normative dimension; ESE: Entrepreneurial self-efficacy; SC: Social capital; UE: University education.

Source: own study. 
In terms of the relationship between country institutional profile and the cognitive process of entrepreneurship, the normative dimension is not directly related to entrepreneurial intention but strongly affects the intention to become an entrepreneur through entrepreneurial self-efficacy and perceived behavioural control ( $\nu_{\text {indirect ND-El }}=\gamma_{\text {total ND-El }}=0.235$ ). The normative dimension appeared as also directly and indirectly related to attitude towards entrepreneurship $\left(\gamma_{\text {direct ND-ATE }}=0.108 ; \gamma_{\text {indirect ND-ATE }}=0.091\right.$; $\gamma_{\text {total ND-ATE }}=0.199$ ). Moreover, the regulatory dimension - although lacking a direct influence on entrepreneurial self-efficacy - slightly affected the attitude towards entrepreneurship $\left(\gamma_{\text {direct RD-PBC }}=0.062\right)$ and perceived behaviour $\left(\gamma_{\text {direct RD-ATE }}=0.025\right)$. Moreover, university education had a strong and positive impact on entrepreneurial self-efficacy $\left(\nu_{\text {direct UE-ESE }}=0.068\right)$. It also had a direct and indirect effect on perceived behavioural control $\left(\nu_{\text {total }}\right.$ UE-PBC $\left.=0.053\right)$, attitude towards entrepreneurship $\left(\nu_{\text {total UE-ATE }}=0.092\right)$, and entrepreneurial intention $\left(\gamma_{\text {total }}\right.$ UE-El $\left.=0.165\right)$.

\section{CONCLUSIONS}

Although prior studies interested in exploring the impacts of individual and environmental factors on the intention to become an entrepreneur, few studies integrated these variables into a single framework (Clercq, Lim, \& Oh, 2011; Nguyen, 2020). Moreover, some researchers argue that environmental factors are internalised by individual characteristics to shape a nascent entrepreneurs' process of entrepreneurship (Nguyen et al., 2018). However, the mechanisms underlying peoples' cognitive process of entrepreneurship that internalise environmental factors have not been adequately explained. Thus, this study combined the theory of planned behaviour (Ajzen, 1991) and the social learning theory (Bandura, 1977) with contextual factors so as to discover these mechanisms.

Thus, this study contributes to entrepreneurship literature by, firstly, revealing that attitude towards entrepreneurship has the strongest effect on entrepreneurial intention, followed by start-up self-efficacy and perceived behavioural control. The study finds that subjective norm is not directly related to entrepreneurial intention, but it has an indirect impact on the intention to become an entrepreneur through attitude towards entrepreneurship and perceived behavioural control. In other words, start-up self-efficacy, attitude towards business venturing, and perceived behavioural control play mediating roles in the correlation between subjective norms and entrepreneurial intention. Secondly, this research reveals the links between social capital and the intention to engage in business venture, which however is not statistically significant and is mediated by attitude towards business venture, subjective norms, and perceived behavioural control. Thirdly, university education appears to not only directly shape entrepreneurial intention but also affect the three antecedents of TPB. Fourthly, while the normative dimension is not related to entrepreneurial intention, the relationship between the regulatory dimension and entrepreneurial intention is rather weak. Moreover, attitude towards entrepreneurship mediates the link between normative dimension and entrepreneurial intention but does not mediate the regulatory dimension and intention to become an entrepreneur. Finally, the findings of this study helps policymakers in ameliorating the entrepreneurship ecosystem - including regulatory and normative support - in order to promote business venturing activities among the youth, especially college students. Furthermore, universities and institutions should design entrepreneurial courses and practical programmes that will support students in acquiring the necessary knowledge and skills to run own businesses after graduation. With an effective supporting scheme, university education can enhance students' attitude towards entrepreneurship, self-efficacy, perceived behavioural control, and then foster entrepreneurial intention, even their future start-up behaviour.

This research has several limitations. Firstly, the number of universities selected to distribute questionnaires was not sufficiently large (only 14 universities and institutions), so future research should survey wider. Secondly, the study only examined factors that affect entrepreneurial intention, without scrutinising the correlation between entrepreneurial intention and actual entrepreneurial behaviour. Future studies should consider this relationship. Moreover, due to resource limitations, this study examined the influence of contextual factors - such as social capital, university education, 
regulatory and normative support - on entrepreneurial intention, while there are many other environmental factors. Thus, future studies should extend the research model or apply another theory so as to contribute to the entrepreneurship literature.

\section{REFERENCES}

Akanbi, S.T. (2013). Familial factors, personality traits and self-efficacy as determinants of entrepreneurial intention among vocational based college of education students in OYA state, Nigeria. The African Symposium: An Online Journal of the African Educational Research Network, 13(2), 66-76.

Ali, A., \& Yousuf, S. (2019). Social capital and entrepreneurial intention: empirical evidence from rural community of Pakistan. Journal of Global Entrepreneurial Research, 9, 64. https://doi.org/10.1186/s40497-019-0193-z

Anderson, J.C., \& Gerbing, D.W. (1988). Structural equation modelling in practice: A review and recommended two-step approach. Psychological Bulletin, 103(3), 411-423.

Ajzen, I. (1991). The theory of planned behavior. Organizational Behavior and Human Decision Processes, 50, 179-211. https://doi.org/10.1016/0749-5978(91)90020-T

Ajzen, I., \& Fishbein, M. (2005). The influence of attitudes by a reasoned action approach: Comment on Ogden (2003). Health Psychology, 22, 424-428.

Bandura, A. (1977). Social Learning Theory. Englewood Cliffs, NJ: Prentice Hall.

Bandura, A. (1982). Self-efficacy mechanism in human agency. American Psychologist, 37, 122-147.

Baughn, C., Lim, V.A., Le, L.T.M., Neupert, K.E., \& Woods, L.S. (2004). Identification of entrepreneurial opportunities in Asia. In J. Butler (Ed.), Opportunity Identification and Entrepreneurial Behavior (pp. 191-218). Greenwich, Conn: Information Age Publishing.

Bentler, P.M., \& Bonett, D.G. (1980). Significance tests and goodness of fit in the analysis of covariance structures. Psychological Bulletin, 88(3), 588-606. https://doi.org/10.1037/0033-2909.88.3.588

Bercovitz, J., \& Feldman, M. (2008). Academic entrepreneurs: Organizational change at the individual level. Organization Science, 19(1), 69-89. https://doi.org/10.1287/orsc.1070.0295

Bhagavatula, S., Elfring, T., van Tilburg, A., \& van de Bunt, G.G. (2010). How social and human capital influence opportunity recognition and resource mobilization in India's handloom industry. Journal of Business Venturing, 25, 245-260. https://doi.org/10.1016/j.jbusvent.2008.10.006

Bird, B., \& Jelinek, M. (1988). The operation of entrepreneurial intentions. Entrepreneurship Theory and Practice, 13(2), 21-29. https://doi.org/10.1177/104225878801300205

Bird, B., \& Brush, C.G. (2002). A gender perspective on organizational creation. Entrepreneurship Theory and Practice, 26(3), 41-65. https://doi.org/10.1177/104225870202600303

Boyd, N.G., \& Vozikis, G.S. (1994). The influence of self-efficacy on the development of entrepreneurial intentions and actions. Entrepreneurship Theory and Practice, 18, 63-90. https://doi.org/10.1177/104225879401800404

Bruton, G., \& Ahlstrom, D. (2003). An Institutional View of China's Venture Capital Industry. Explaining the Differences between China and the West. Journal of Business Venturing, 18(2), 233-259. https://doi.org/10.1016/S0883-9026(02)00079-4

Busenitz, L., Gomez, C., \& Spencer, J. (2000). Country institutional profile: Unlocking entrepreneurial phenomena. Academy of Management Journal, 45(5), 994-1003.

Camelo-Ordaz, C., Dianez-Gonzalez, J.D., \& Ruiz-Navarro, J. (2016). The influence of gender on entrepreneurial intention. The mediating role of perceptual factors. Business Research Quartely, 19, 261-277. https://doi.org/10.1177/2515127420961040

Chia, C.C., \& Liang, C. (2016). Influence of Creativity and Social Capital on the Entrepreneurial Intention of Tourism Students. Journal of Entrepreneurship, Management and Innovation, 12(2), 151-168. https://doi.org/10.7341

Cox, L.W., Mueller, S.L., \& Moss, S.E. (2002). The impact of entrepreneurship education on entrepreneurial selfefficacy. International Journal of Entrepreneurship Education, 1(2), 229-245.

Davidsson, P., \& Honig, B. (2003). The role of social and human capital among nascent entrepreneurs. Journal of Business Venturing, 18, 301-331. https://doi.org/10.1016/S0883-9026(02)00097-6 
Edelman, L.F., Manolova, T., Shirokova, G., \& Tsukanova, T. (2016). The impact of family support on young entrepreneurs' start-up activities. Journal of Business Venturing, 31(4), 428-448. https://doi.org/10.5465/AMBPP.2015.11116abstract

Fini, R., Grimaldi, R., Marzocchi, G.L., \& Sobrero, M. (2012). The determinants of corporate entrepreneurial intention within small and newly established firms. Entrepreneurship Theory and Practice, 36, 387-414.

Fornell, C., \& Larcker, D.F. (1981). Evaluating Structural Equation Models with Unobservable Variables and Measurement Error. Journal of Marketing Research, 18(1), 39-50.

Gorgievski, M.J., Stephan, U., Laguna, M., \& Moriano, J.A. (2017). Predicting Entrepreneurial Career Intentions: Values and the theory of planed behavior. Journal of Career Assessment, 26(3), 457-475.

Hair, J.F., Jr., Black, W.C., Babin, B.J., \& Anderson, R.E. (2010). Multivariate data analysis: A global perspective (7th ed.). Upper Saddle River, New Jersey: Pearson Education International, Prentice Hall.

Hand, C., Iskandarova, M., \& Blackburn, R. (2020). Founders' social identity and entrepreneurial self-efficacy amongst nascent entrepreneurs: A configurational perspective. Journal of Business Venturing Insights, 12, e00160. https://doi.org/10.1016/j.jbvi.2020.e00160

Hayton, J.C., George, G., \& Zahra, S. (2002). National culture and entrepreneurship: A review of behavioral research. Entrepreneurship Theory and Practice, 26(4), 33-51. https://doi.org/10.1177/104225870202600403

Hederson, R., \& Robertson, M. (2000). Who Wants to be An Entrepreneur? Young Adult Attitudes to Entrepreneurship as A Career. Career Development International, 5(6), 279-287. https://doi.org/10.1108/13620430010373755

Hoang, G., Le, T.T.T., Tran, T.K.A., \& Du, T. (2020). Entrepreneurship education and entrepreneurial intention of university students in Vietnam: the mediating roles of self-efficacy and learning orientation. Education \& Training, https://doi.org/10.1108/ET-05-2020-0142

Hu, L., \& Bentler, P.M. (1999). Cut-off criteria for fit indexes in covariance structure analysis: Conventional criteria versus new alternatives. Structural Equation Modeling, 6(1), 1-55.

Jöreskog, K.G., \& Sörbom, D. (1993). LISREL VIII: A guide to the program and applications, 3rd Ed. Chicago: SPSS.

Kruja-Demneri, A. (2020). Entrepreneurial Orientation, Synergy and Firm Performance in the Agribusiness Context: An Emerging Market Economy Perspective. Central European Business Review, 9(1), 56-75. https://doi.org/10.18267/j.cebr.229

Krueger, N.F., \& Carsrud, A.L. (1993). Entrepreneurial intentions: Applying the theory of planned behavior. Entrepreneurship and Regional Development, 5, 315-330. https://doi.org/10.1080/08985629300000020

Lang, R., \& Fink, M. (2019). Rural social entrepreneurship: The role of social capital within and across institutional levels. Journal of Rural Studies, 70, 155-168. https://doi.org/10.1016/j.jrurstud.2018.03.012

Lavelle, B.A. (2019). Entrepreneurship Education's Impact on Entrepreneurial Intention Using the Theory of Planned Behavior: Evidence From Chinese Vocational College Students. Entrepreneurship Education and Pedagogy, 4(1), 30-51. https://doi.org/10.1177/2515127419860307

Liñán, F. (2008). Skill and value perceptions: how do they affect entrepreneurial intention. International Entrepreneurship and Management Journal, 4, 257-272. https://doi.org/10.1007/s11365-008-0093-0

Liñán, F., \& Chen, Y.W. (2009). Development and cross-cultural application of a specific instrument to measure entrepreneurial intentions. Entrepreneurship Theory and Practice, 33, 593-617. https://doi.org/10.1111/j.1540-6520.2009.00318.x

Liñán, F., Nabi, G., \& Krueger, N. (2013). British and Spanish entrepreneurial intentions: A comparative study', La intención emprendedora en reino unido y españa: Un estudio comparativo, 33(1), 73-103. Retrieved from https://www.academia.edu/3532701/British_and_Spanish_Entrepreneurial_Intentions_A_Comparative_Study on April, 20, 2020.

Liñán, F., Santos, F.J., \& Fernández, J. (2011). The influence of perceptions on potential entrepreneurs. International Entrepreneurship and Management Journal, 7(3), 373-390. https://doi.org/10.1007/s11365-0110199-7

Lortie, J., \& Castogiovanni, G. (2015). The theory of planned behavior in entrepreneurship research: what we know and future directions. International Entrepreneurship and Management Journal, 1, 935-957. https://doi.org/10.1007/s11365-015-0358-3 
Mahfud, T., Triyono, M.B., Sudira, P., \& Mulyani, Y. (2020). The influence of social capital and entrepreneurial attitude orientation on entrepreneurial intentions: the mediating role of psychological capital. European Research on Management and Business Economics, 26, 33-39.

Maes, J., Leroy, H., \& Sels, L. (2014). Gender differences in entrepreneurial intentions: A TPB multi-group analysis at factor and indicator level. European Management Journal, 32, $784-794$. https://doi.org/10.1016/j.emj.2014.01.001

Maresch, D., Harms, R., Kailer, N., \& Wurm, W.B. (2015). The impact of entrepreneurship education on entrepreneurial intention of students in science and engineering versus business studies university programs. Technological Forecasting \& Social Change, 104, 172-192. https://doi.org/10.1016/j.techfore.2015.11.006

Marshall, D.R., Meek, W.R., Swab, R.G., \& Markin, E. (2020). Access to resources and entrepreneurial wellbeing: A self-efficacy approach. Journal of Business Research, 120, $203-212$. https://doi.org/10.1016/j.jbusres.2020.08.015

McEachan, R.R.C., Conner, M., Taylor, N.J., \& Lawton, R.J. (2011). Prospective prediction of health-related behaviours with the theory of planned behaviour: A meta-analysis. Health Psychology Review, 5, 97-144. https://doi.org/10.1080/17437199.2010.521684

Meoli., A., Fini, R., Sobrero, M., \& Wiklund, J. (2020). How entrepreneurial intentions influence entrepreneurial career choices: The moderating influence of social context. Journal of Business Venturing, 35, 1-20. https://doi.org/10.1016/j.jbusvent.2019.105982

Miranda, F.J., Chamorro-Mera, A., \& Rubio, S. (2017). Academic entrepreneurship in Spanish university: An analysis of determinants of entrepreneurial intention. European Research on Management and Business Economics, 23, 113-222. https://doi.org/10.1016/j.iedeen.2017.01.001

Mozahem, \& Adlouni, R. (2020). Using entrepreneurial self-efficacy as an indirect measure of entrepreneurial education. The International Journal of Management Education, https://doi.org/10.1016/j.ijme.2020.100385

Morris, M.H., \& Tsukanova, T. (2017). Student entrepreneurship and the university ecosystem: A multy-country empirical exploratory. European Journal of International Management, 11(1), 65-85. https://doi.org/10.1504/EJIM.2017.081251

Mueller, S.L., \& Thomas, A.S. (2001). Culture and entrepreneurial potential: A nine country study of locus of control and innovativeness. Journal of Business Venturing, 16(1), 51-75. https://doi.org/10.1016/S08839026(99)00039-7

Neto, R., Rodrigues, V., Steward, D., Xiao, A., \& Snyder, J. (2018). The influence of self-efficacy on entrepreneurial behaviour among K-12 teacher. Teaching and Teacher Education, 72, 44-53. https://doi.org/10.1007/s41959-020-00030-8

Nguyen, T.T. (2020). The Impact of Access to Finance and Environmental Factors on Entrepreneurial Intention: The Mediator Role of Entrepreneurial Behavioural Control. Entrepreneurial Business and Economics Review, 8(2), 127-140. https://doi.org/10.15678/EBER.2020.080207

Nguyen, V.T., Nguyen, T.L., \& Nguyen, H.H. (2018). Fostering academic entrepreneurship: A qualitative study of invention commercialization. Journal of Development Entrepreneurship, 23(4), 1-23.

Nguyen, T.V., Bryant, S.E., Rose, J.W., Tseng, C., \& Kapasuwan, S. (2009). Culture value, market institutions, and entrepreneurship potential: A comparative study of the United States, Taiwan, and Vietnam. Journal of Developmental Entrepreneurship, 14(01), 21 37. https://doi.org/10.1142/s1084946709001120

Nguyen, P.M., Dinh, V.T., Luu, T.-M.-N., \& Choo, Y. (2020). Sociological and theory of planned behaviour approach to understanding entrepreneurship: Comparison of Vietnam and South Korea. Cogent Business \& Management, 7(1), 1815288. https://doi.org/10.1080/23311975.2020.1815288

Nunnally, J.C., \& Bernstein, I.H. (1994). The Assessment of Reliability. Psychometric Theory, 3, 248-292.

Oftedal, E.M., lakovleva, T., \& Foss, L. (2017). University context matter: An institutional perspective on entrepreneurial intentions of students. Education and Training, https://doi.org/10.1108/ET-06-2016-0098

Othman, N., \& Mansor, M. (2012). Entrepreneurial intentions among polytechnic students in Malaysia. International Business Management, 6(4), 517-526. https://doi.org/10.3923/ibm.2012.517.526

Preacher, K.J., \& Hayes, A.F. (2008). Asymptotic and resampling strategies for assessing and comparing indirect effects in multiple mediator models. Behavior Research Methods, 40(3), 879-891. https://doi.org/10.3758/BRM.40.3.879 
Poon., J.P.H., Thai, D.T., \& Naybor, D. (2012). Social capital and female entrepreneurship in rural regions: Evidence from Vietnam. Applied Geography, 35, 308-315. https://doi.org/10.1016/j.apgeog.2012.08.002

Rondinelli, D.A., \& Kasarda, J.D. (1992). Foreign trade potential, small enterprise development and job creation in developing countries. Small Business Economics, 4, 253-265. Retrieved from https://www.jstor.org/stable/40228838 on April, 2, 2020.

Saeed, S., Yousafzai, S.Y., Yani-de-soriano, M., \& Muffatto, M. (2015). The Role of Perceived University Support in the Formation of Students' Entrepreneurial Intention. Journal of Small Business Management, 53(4), 11271145. https://doi.org/10.1111/jsbm.12090

Segal, G., Borgia, D., \& Schoenfeld, J. (2005). The motivation to become an entrepreneur. International Journal of Entrepreneurial Behaviour \& Research, 11(1), 42-57. Retrieved from https://www.deepdyve.com/lp/emerald-publishing/the-motivation-to-become-an-entrepreneur-vlOsOgEXnB on April, 2, 2020.

Shane, S., \& Venkataraman, S. (2000). The promise of entrepreneurship as a field of research. Academy of Management Review, 25(1), 217-226. https://doi.org/10.12691/jbe-3-1-2

Shrout, P.E., \& Bolger, N. (2002). Mediation in experimental and nonexperimental studies: New procedures and recommendations. Psychological Methods, 7(4), 422-445. https://doi.org/10.1037/1082-989X.7.4.422

Solesvik, M.Z. (2013). Entrepreneurial motivations and intentions: Investigating the role of education major. Education and Training, 55(3), 253-271. https://doi.org/10.2139/ssrn.2624796

Spencer, J.W., \& Gomez, C. (2004). The relationship among national institutional structures, economic factors, and domestic entrepreneurial activity: A multi-country study. Journal of Business Research, 57(10), 1098-1107. https://doi.org/10.1016/S0148-2963(03)00040-7

Sullivan, S.E., \& Baruch, Y. (2009). Advances in Career Theory and Research: A Critical Review and Agenda for Future Exploration. Journal of Management, 35(6), 1542-1571. https://doi.org/10.1177/0149206309350082

Traikova, D., Manolova, T.S., Mollers, J., \& Buchenrieder, G. (2017). Corruption perceptions and entrepreneurial intentions in a transitional context-the case of rural Bulgaria. Journal of Developmental Entrepreneurship, 22(3), 1-17. Retrieved from https://www.worldscientific.com/worldscinet/jde on April 20, 2020.

Tsai, K.H., Chang, H.C., \& Peng, C.Y. (2014). Extending the link between entrepreneurial self-efficacy and intention: A moderated mediation model. International Entrepreneurship and Management Journal, 12(2), 445463. https://doi.org/10.1007/s11365-014-0351-2

To, C.K.M., Martínez, J.M.G., Orero-Blat, M., \& Chau, K.P. (2020). Predicting motivational outcomes in social entrepreneurship: Roles of entrepreneurial self-efficacy and situation fit. Journal of Business Research, 121, $209-222$. https://doi.org/10.1016/j.jbusres.2020.08.022

Tung, D.T., Hung, N.T., Phuong, N.T.C., Loan, N.T.T., \& Chong, S.S. (2020). Enterprise development from students: The case of universities in Vietnam and the Philippines. The International Journal of Management Education, 18(1), 100333. https://doi.org/10.1016/j.ijme.2019.100333

Turker, D., \& Selcuk, S.S. (2009). Which factors affect entrepreneurial intention of university students?. Journal of European Industrial Training, 33(2), 142-159. https://doi.org/10.1108/03090590910939049

Turulja, L., Veselunovic, L., Agic, E., \& Pasic-Mesihovic, A. (2020). Entrepreneurial intention of students in Bosnia and Herzegovina: what type of support matters?. Economic Research-Ekonomska Istraživanja, 33(3), 1-20. https://doi.org/10.1080/1331677X.2020.1730216

Uddin, M.R., \& Bose, T.K. (2012). Determinants of entrepreneurial intention of business students in Bangladesh. International Journal of Business and Management, 7(24), 128. https://doi.org/10.5539/ijbm.v7n24p128

Vancea, M., \& Utzet, M. (2017). Does Unemployment and Precarious Employment Lead to Increasing Entrepreneurial Intentions among Young People? Results from a Survey-Based Study in Spain. Central European Business Review, 6(2), 5-17. https://doi.org/10.18267/j.cebr.176

Wang, C.K., \& Wong, P.K. (2004). Entrepreneurial interest of university students in Singapore. Technovation, 24(2), 163-72. https://doi.org/10.1016/S0166-4972(02)00016-0

Wąsowska, A. (2016). Who Doesn't Want to be an Entrepreneur? The Role of Need for Closure in Forming Entrepreneurial Intention of Polish Students. Entrepreneurial Business and Economics Review, 4(3), 27-39. https://doi.org/10.15678/EBER.2016.040303

Yang, M.M., Li, T., \& Wang, Y. (2020). What explains the degree of internationalization of early stage entrepreneurial firms? A multilevel study on the joint effects of entrepreneurial self-efficacy, opportunity-motivated 
entrepreneurship, and home country institutions. Journal of World Business, 55(6), 101114. https://doi.org/10.1016/j.jwb.2020.101114

Vuković, K., Kedmenec, I., Postolov, K., Jovanovski, K., \& Korent., D. (2017). The role of bonding and bridging cognitive social capital in shaping entrepreneurial intention in transition economies. Management, 22(1), 133. https://doi.org/10.30924/mjcmi/2017.22.1.1

Yoon, H., Yun, S., Lee, J., \& Phillips, F. (2015). Entrepreneurship in East Asian Regional Innovation System: Role of social capital. Technological Forecasting and Social Change, 100, 83-95. https://doi.org/10.1016/j.techfore.2015.06.028

Zamrudi, Z., \& Yulianti, F. (2020). Sculpting Factor of Entrepreneurship Among University Students in Indonesia. Entrepreneurial Business and Economics Review, 8(1), 33-49. https://doi.org/10.15678/EBER.2020.080102 


\section{Author}

\section{Doanh Duong Cong}

PhD in Business Management (2019, National Economics University, Vietnam \& University of Szczecin, PolandErasmus Mundus Programme); Master of Science in Management (2016, KEDGE Business School, France); Bachelor of Business Administration (2011, National Economics University, Vietnam). His research interests include entrepreneurship, corporate social responsibility, and green consumption.

Correspondence to: Doanh Duong Cong, PhD, Department of General Management, Faculty of Business Management, National Economics University, 207 Giai Phong, Hanoi, Vietnam, e-mail: doanhdc@neu.edu.vn ORCID (1) http://orcid.org/0000-0003-4431-9761

\section{Acknowledgements and Financial Disclosure}

The article came into being within the project no. 339/QD-DHKTQD, financed by National Economics University, 2020.

\section{Conflict of Interest}

The author declares that the research was conducted in the absence of any commercial or financial relationships that could be construed as a potential conflict of interest.

\section{Copyright and License}

This article is published under the terms of the Creative Commons Attribution - NoDerivs (CC BY-ND 4.0) License http://creativecommons.org/licenses/by-nd/4.0/ 